\title{
Pengaruh E-Commerce Terhadap Perilaku Konsumen Tokopedia Pada Masyarakat Kota Jambi
}

\author{
${ }^{1}$ Gita Silvia, ${ }^{2}$ kasful Anwar \\ 1-2 Jurusan Ekonomi Syariah, Fakultas Ekonomi dan Bisnis Islam, Universitas Negeri Sulthan Thaha \\ Saifuddin Jambi
}

\author{
Article history \\ Received: 02-03-2021 \\ Revised: 10-04-2021 \\ Accepted: 09-05-2021 \\ *Corresponding Author: \\ Gita Silva, \\ Kafsul Anwar US, \\ Jurusan Ekonomi Syariah, \\ Fakultas Ekonomi dan \\ bisnis Islam, \\ Universitas Negeri Sulthan \\ Thaha Saifuddin Jambi \\ Email: gitag438@gmail.co \\ $\underline{\mathrm{m}}$
}

\begin{abstract}
Abstrak: E-Commerce memiliki dampak yang sangat besar dalam dunia bisnis, terutama pada proses penyempurnaan marketing perusahaan demi mencapai tujuan perusahaan demi mencapai tujuan perusahaan itu sendiri. Metode pengumpulan data dalam penelitian ini menggunakan penelitian kepustakaan dan penelitian lapangan dengan mengumpulkan data menggunakan teknik kuesioner atau mengumpulkan data dengan menyusun daftar pernyataan. Tokopedia merupakan perusahaan Teknologi di Indonesia dengan spesialisasi dibidang bisnis marketplace (E-Commerce). Tokopedia berdiri pada tanggal 6 Februari 2009 oleh William Tanuwijaya dan Leontinus Alpha Edison dibawah naungan PT. Tokopedia dan resmi luncur ke publik pada tanggal 17 Agustus 2009. Berdasarkan hasil penelitian regresi sederhana dengan Nilai $Y=0,423+0,843$, dengan nilai $R$ Square 0.681. Secara uji t,

ECommerce berpengaruh terhadap perilaku konsumen pada masyarakat Kota Jambi, dengan nilai signifikan sebesar $0,000<0,05$. Dalam penelitian ini, penulis memberikan saran yaitu diharapkan dapat digunakan oleh masyarakat kota Jambi untuk memperhatikan penggunaan media internet dan memperhatikan perilaku yang terkait faktor psikologi untuk membentuk perilaku konsumen yang lebih baik.
\end{abstract}

Kata Kunci : E-Commerce,Perilaku Konsumen, Tokopedia

\section{PENDAHULUAN}

Menurut Kotler dan Amstrong (Alma, 2018:131) manajemen pemasaran adalah kegiatan menganalisa, merencanakan, mengimplementasi, dan mengawasi segala kegiatan (program), guna memperoleh tingkat pertukaran yang menguntungkan dengan pembeli sasaran dalam rangka mencapai tujuan organisasi. Menurut William J. Shultz dalam (Alma, 2018:131) manajemen pemasaran adalah merencanakan, pengarahan dan pengawasan seluruh kegiatan pemasaran perusahaan ataupun bagian dari perusahaan.

Perkembangan dalam dunia bisnis memunculkan istilah-istilah baru yang tidak asing lagi bagi kita, seperti halnya E-Commerce, e-business, e-learning dan istilah sejenis yang beredar. E-Commerce memiliki dampak yang sangat besar dalam dunia bisnis, terutama pada proses penyempurnaan marketing perusahaan demi mencapai tujuan perusahaan demi mencapai tujuan perusahaan itu sendiri. E-Commerce seperti penghubung antara penyedia jasa atau barang dengan konsumen. Melalui E-Commerce, setiap pribadi memiliki kesempatan dan peluang yang sama untuk berhasil dan bersaing dalam dunia bisnis di dunia maya (Aco, 2017:1). E-Commercesama dengan pasar di dunia fisik dan proses transaksi di dunia nyata (fisik). Yang membedakannya adalah kegiatanyya dilakukan secara online dan digital (tanpa melibatkan tatap muka langsung antar penjual dan pembeli) serta sedikit perbedaan pada proses bisnis didalamnya. (Pratama, 2017: 8).

Konsumen yang memanfaatkan E-Commerce ini tidak hanya yang sudah berumah tangga tetapi dari usia SMP, SMA/SMK sederajatpun mereka sudah memanfaatkannya, karena aplikasi ini terbilang mudah untuk dijangkau dengan smart phone yang mereka punya. Tidak 
harus mempunyai toko nyata untuk bisa menggunakan aplikasi ini tetapi dengan cara yang mudah pun produsen bisa menawarakan produknya. Saya melihat bahwa banyaknya masyarakat yang sangat memanfaatkan E-Commerce ini untuk menambah penghasilan, tetapi banyak juga mereka yang hanya sebagai konsumen. Konsumen seringnya mengeluh karena tidak bisa mengendalikan perilaku konsumtifnya. Sehingga mempengaruhi perilaku konsumtif masyarakat, dampak dari perilaku konsumtif juga tidak baik karena akan melemahkan perekonomian individu

Perubahanan perilaku konsumen dalam E-Commerce merupakan tantangan sendiri bagi perusahaaan agar dapat memenuhi kebutuhan dan keinginan konsumennya. Data yang dirilis oleh Menkominfo menunjukkan bahwa nilai transaksi online shopping pada ECommerce tahun 2020 mengalami kenaikan hingga mencapai 140 juta dibandingkan tahun lalu yaitu 80 juta. Sehingga dapat dipahami bahwa potensi E-Commerce sangat terbuka luas dengan membuat venture capital menanamkan modalnya ke perusahaan E-Commerce di Indonesia.

Perkembangan internet memang cepat dan memberi pengaruh signifikan dalam segala aspek kehidupan. Internet membantu kita sihingga dapat berinteraksi, berkomunikasi bahkan melakukan perdagangan dengan orang lain dari segala pejuru dunia dengan murah, cepat dan mudah. Salah satu manfaat dari keberadaan internet adalah sebagai media promosi suatu produk. Suatu produk yang muncul melalui internet dapat membawa keuntungan bagi pengusaha yang ingin memulai usahanya karena produknya lebih mudah untuk dikenal (Le dan Denny, 2013)

Alasan mengapa pentingnya perusahaan menggunakan E-Commerce yaitu media iklan harus mengikuti dengan asumsi bahwa tujuan periklanan manapun adalah untuk menjangkau target audiens secara efektif dan efisien. Para pengiklan mengakui bahwa mereka harus melakukan penyesuaian perencanaan pemasarannya untuk terus mengejar peningkatan jumlah orang yang menghabiskan waktu didepan computer online maupun jenis elektronik lain yang terhubung dengan akses internet.

Salah satu situs internet di Indonesia yang menerapkan konsep E-Commerce adalah situs website Tokopedia. Tokopedia.com merupakan salah satu mall online di Indonesia yang mengusung model bisnis marketplace dan mall online. Tokopedia memungkinkan setiap individu, toko kecil dan brand untuk membuka dan mengelola toko online (Lestari, 2019:479). Sejak diluncurkan sampai hingga akhir 2015, layanan dasar Tokopedia bisa digunakan oleh semua orang secara gratis. Tokopedia.com resmi diluncurkan ke publik pada 17 Agustus 2009 di bawah naungan PT Tokopedia yang didirikan oleh William Tanuwijaya dan Leontinus Alpha Edison pada 6 Februari 2009. Sejak resmi diluncurkan, PT Tokopedia berhasil menjadi salah satu perusahaan internet Indonesia dengan pertumbuhan yang sangat pesat (id.wikipedia.org).

Selain membeberkan data aplikasi dengan pengguna aktif dan unduhan terbanyak sepanjang 2020. iPrice membagikan 10 situs E-Commerce yang paling banyak dikunjungi dan tetap didominasi oleh Tokopedia.

Tabel 1 Pengunjung E-Commerce Tokopedia.com

\begin{tabular}{clll}
\hline No & & Jenis E-Commerce & Pengunjung \\
\hline 1 & Tokopedia & 75.502 .688 \\
2 & Shopee & 61.669 .392 \\
3 & Bukalapak & 53.862 .335 \\
4 & Lazada & 28.722 .575
\end{tabular}




\begin{tabular}{cll}
5 & Blibli.com & 24.170 .104 \\
6 & JD.id & 7.487 .384 \\
7 & Sociolla & 4.262 .023 \\
8 & Bhinneka & 4.164 .203 \\
9 & Orami & 3.873 .176 \\
10 & Zalora & 3.046 .010 \\
\hline
\end{tabular}

Sumber: iPrice, 2020

PT Tokopedia mendapatkan seed funding (pendanaan awal) dari PT Indonusa Dwitama pada tahun 2009. Kemudian pada tahun-tahun berikutnya, Tokopedia kembali mendapatkan suntikan dana dari pemodal ventura global seperti East Ventures (2010), Cyber Agent Ventures (2011), Netprice (2012, dan SoftBank Ventures Korea (2013). Hingga pada Oktober 2014, Tokopedia berhasil mencetak sejarah sebagai perusahaan teknologi pertama di Asia Tenggara, yang menerima investasi sebesar USD 100 juta atau sekitar Rp 1,2 triliun dari Sequoia Capital dan Soft Bank Internet and Media Inc (SIMI). Berkat peranannya dalam mengembangkan bisnis online di Indonesia, PT Tokopedia berhasil meraih penghargaan Marketeers of the Year 2014 untuk sektor E-Commerce pada acara Markplus Conference 2015 yang digelar oleh Markplus Inc. tanggal 11 Desember 2014 (id.wikipedia.org)

Kota Jambi yang jumlah penduduknya semakin meningkat dari tahun ke tahun, dapat dilihat pada Tabel berikut ini:

Tabel 1.2 Jumlah Penduduk Usia Produktif Kota Jambi Tahun 2015-2019

\begin{tabular}{llll}
\hline No & Tahun & Penduduk Produktif (Jiwa) & Perkembangan $(\%)$ \\
\hline 1 & 2015 & 406.567 & - \\
2 & 2016 & 413.359 & 1,64 \\
3 & 2017 & 420.288 & 1,65 \\
4 & 2018 & 426.612 & 1,48 \\
5 & 2019 & 431.897 & 1,22 \\
\hline
\end{tabular}

Sumber: BPS Kota Jambi, 2019

Dari tabel 1 di atas dapat disimpulkan bahwa setiap tahun Kota Jambi mengalami peningkatan jumlah penduduk. Pada tahun 2016 jumlah penduduk produktif sebanyak 413.359 jiwa perkembangan 1,64\%, tahun 2017 jumlah penduduk produktif sebanyak 420.288 jiwa perkembangan 1,65\%, tahun 2018 jumlah penduduk produktif sebanyak 426.612 jiwa perkembangan 1,48\%, dan tahun 2019 usia penduduk produktif di Kota Jambi sebanyak 431.897 jiwa persentase $1,22 \%$.

Berdasarkan uraian diatas maka peneliti tertarik melakukan penelitian dengan judul:

"Pengaruh E-Commerce Terhadap Perilaku Konsumen Tokopedia Pada Masyarakat Kota Jambi."

\section{LANDASAN TEORI}

\section{Manajemen Pemasaran}

Menurut Kotler dan Amstrong (Alma, 2018:131) manajemen pemasaran adalah kegiatan menganalisa, merencanakan, mengimplementasi, dan mengawasi segala kegiatan (program), guna memperoleh tingkat pertukaran yang menguntungkan dengan pembeli sasaran dalam rangka mencapai tujuan organisasi. Menurut William J. Shultz (Alma, 2018:131) manajemen pemasaran adalah merencanakan, pengarahan dan pengawasan seluruh kegiatan pemasaran 
perusahaan ataupun bagian dari perusahaan.

Menurut Ben M. Enis dalam (Alma, 2018:131) manajemen pemasaran ialah proses untuk meningkatkan efisiensi dan efektivitas dari kegiatan pemasaran yang dilakukan oleh indivisu atau oleh perusahaan. Logika dari definisi diatas, ialah apabila seseorang atau perusahaan, ingin memperbaiki pemasarannya, maka ia harus melakukan kegiatan pemasaran itu sebaik mungkin.

Berdasarkan uraian tersebut, maka yang dimaksud dengan manajemen pemasaran adalah ilmu dan seni dalam melaksanakan fungsi-fungsi manajemen yang terdiri dari perencanaan, pengorganisasian, mengaktualisasikan, serta pengendalian dalam rangka menyampaikan produk dan lain-lain yang terkandung didalamnya dari pihak produsen ke konsumen.

\section{E-Commerce}

Secara sederhana E-Commerce digunakan untuk menunjukkan pembelian dan penjualan menggunakan teknologi internet. Tetapi istilah E-Commerce itu sendiri bukan hanya sekedar transaksi keuangan secara elektronik melalui bisnis dan konsumen saja melainkan juga merujuk pada semua mediasi transaksi secara elektronik antara bisnis dan pihak ketiga. (Anggiani, 2016:218)

E-Commerce adalah transaksi jual beli secara elektronik melalui media internet tanpa harus tatap muka antara penjual dan pembeli (Nurjanah, 2019:156). Menurut Suyanto (2003:11), E-Commerce merupakan proses jual beli atau pertukaran produk, jasa dan informasi melalui jaringan informasi seperti internet.

Menurut Laudon dan Laudon dalam (Maulana, 2015) E-Commerce adalah suatu proses membeli dan menjual produk-produk secara elektronik oleh konsumen dan dari perusahaan ke perusahaan dengan komputer sebagai perantara transaksi bisnis. Media yang dapat digunakan dalam aktivitas E-Commerce adalah world wide web internet.

Dari berbagai definisi-definisi yang diberikan diatas mengenai E-Commerce, maka dapat diketahui manfaat E-Commerce didalam membantu pengguna computer, baik pelaku bisnis (pedagang, distributor, produsen) maupun konsumen akhir, didalam melakukan jual beli barang dan jasa serta transaksi secara cepat dan mudah berbasiskan internet (Pratama, 2017: 3).

\section{Faktor-faktor E-Commerce}

Beberapa faktor yang penting harus diperhatikan diantaranya yaitu sebagai berikut (Anggiani, 2016: 218)

(a) Menyediakan harga kompetitif,

(b) Menyediakan jasa pembelian yang tanggap cepat dan ramah,

(c) Menyediakan informasi barang dan jasa yang lengkap dan jelas,

(d) Menyediakan banyak bonus seperti kupon, penawaran istimewa, dan diskon (e) Memberikan perhatian khusus seperti ulasan pembelian, (f) Menyediakan rasa komunitas untuk berdiskusi.

Dengan menggunakan E-Commerce wirausaha dapat mengubah daftar harga atau melakukan kustomisasi produk atau jasa yang ditawarkan dan terinformasikan secara cepat melalui website. Sesuatu yang biasanya memerlukan waktu yang lama untuk dilaksanaan atau diintegrasikan dengan E-Commerce menjadi lebih cepat (Anggiani, 2016:220) 


\section{Perilaku Konsumen}

Menurut Loundon dan Bitta (Hurriyati, 2019: 67) perilaku konsumen adalah proses pengambilan keputusan yang mensyaratkan aktivitas individu untuk mengevaluasi, mencari, menggunakan barang dan jasa. Menurut Wilkie (Hurriyati, 2019: 67) perilaku konsumen adalah aktivitas dimana seseorang melibatkan diri dalam proses menyeleksi, membeli dan mempergunakan barang dan jasa sehingga memuaskan kebutuhan dan hasratnya.

Menurut Engel et al (Hurriyati, 2019: 67) perilaku konsumen adalah Tindakan langsung untuk mendapatkan, mengkonsumsi, dan menghabiskan produk dan jasa, termasuk proses keputusan yang mendahului dan mengikuti Tindakan ini. Kotler dan Amstrong (Hurriyati, 2019: 67) perilaku konsumen adalah perilaku pembelian konsumen akhir, baik individu maupun rumah tangga yang membeli produk untuk konsumsi personal.

Berdasarkan pada definisi diatas maka dapat dikatakan bahwa perilaku konsumen merupakan tindakan-tindakan konsumen yang secara langsung dalam proses mendapatkan, mengkonsumsi, dan menghabiskan suatu produk atau jasa yang diharapkan dapat memuaskan kebutuhan mereka.

\section{Faktor-faktor yang Mempengaruhi Perilaku konsumen}

Perilaku konsumen dipengaruhi oleh berbagai macam faktor. Menurut Kotler dan Amstrong (Hurriyati, 2019: 94), faktor-faktor yang mempengaruhi perilaku konsumen terdiri dari budaya, sosial, pribadi dan psikologi.

1. Faktor Budaya

Faktor-faktor budaya memberikan pengaruh paling luas dan dalam tingkah laku konsumen. Pemasar harus mengetahui peran yang dimainkan oleh budaya, subbudaya, dan kelas sosial pembeli. (Wibowo dan Priansa, 2018: 294)

2. Faktor Sosial

Tingkah laku konsumen juga di pengaruhi oleh faktor-faktor sosial seperti kelompok kecil, keluarga, serta peran dan status sosial konsumen.

3. Faktor Pribadi

Keputusan membeli juga dipengaruhi oleh karakteristik pribadi seperti umur dan tahap daur hidup, pekerjaan, situasi ekonomi, gaya hidup, serta kepribadian konsep diri pembeli.

4. Faktor Psikologis

Pilihan barang yang di beli seseorang lebih lanjut dipengaruhi oleh empat faktor psikologis yang penting yaitu motivasi, persepsi, pengetahuan, serta keyakinan dan sikap.

\section{Hipotesis}

Hipotesis merupakan jawaban sementara terhadap rumusan masalah penelitian, dimana rumusan masalah penelitian telah dinyatakan dalam bentuk kalimat pertanyaan (Sugiyono, 2018:63). Adapun hipotesis dalam penelitian ini yaitu:

1. Diduga E-Commerce baik dan perilaku konsumen tinggi di Kota Jambi.

2. Diduga E-Commerce berpengaruh dan signifikan terhadap perilaku konsumen di Kota Jambi.

\section{METODE PENELITIAN}


Metode penelitian yang digunakan dalam penelitian ini adalah metode deskriptif dan kuantitatif. Menurut Hidayat (2006: 72) penelitian deskriptif adalah metode penelitian yang digunakan untuk menentukan pengetahuan yang seluas-luasnya terhadap objek penelitian pada suatu masa tertentu. Penilaian kuantitatif dinamakan metode tradisional, karena metode ini sudah cukup lama digunakan sehingga sudah mentradisi sebagai metode untuk penelitian.

Untuk menganalisis permasalahan diatas digunakan skala penelitian dengan menghitung frekuensi skor item pertanyaan. Seperti yang dikemukakan Umar (2013: 225) bahwa perhitungan skor setiap komponen yang diteliti dengan mengalihkan seluruh frekuensi data dengan nilai bobot. Rumus yang digunakan adalah sebagai berikut:

Dimana:

$$
n=\frac{N}{1+\left(N \times e^{2}\right)}
$$

$\mathrm{n}$ : Ukuran sampel

$\mathrm{N}$ : Populasi

e : error

Dengan menggunakan margin of error sebesar 10\%, maka jumlah sampel yang diambil adalah sebagai berikut:

$$
\begin{aligned}
& n=\frac{431.897}{1+\left(431.897 \times 0,1^{2}\right)} \\
& n=\frac{431.897}{4.319,97} \\
& n=99,97 \text { atau } 100 \text { Responden }
\end{aligned}
$$

Sampel yang diambil pada penelitian ini yaitu 100 responden.

\section{Regresi Linear Sederhana}

Analisis Regresi linear sederhana adalah hubungan secara linier anatar satu variabel independen (E-Commerce) dengan variabel dependen (Perilaku Konsumen).

Rumus:

$$
\mathrm{Y}=\mathrm{a}+\mathrm{bX}+e
$$

Menurut Supranto, 2015:181 Keterangan:

$$
\begin{array}{ll}
\mathrm{a} & =\text { Konstanta } \\
\mathrm{b} & =\text { Koefisien Regresi } \\
\mathrm{X} & =\text { E-Commerce } \\
\mathrm{Y} & =\text { Perilaku Konsumen }
\end{array}
$$

\section{HASIL DAN PEMBAHASAN}

\section{E-Commerce}

Hasil rekap jawaban responden berdasarkan urutan prioritas penilaian E-Commerce di Kota Jambi sebagai berikut:

Tabel 3 Rekapitulasi Jawaban E-Commerce

\begin{tabular}{cclccc}
\hline No & \multicolumn{1}{c}{ Indikator } & \multicolumn{1}{c}{ Pernyataan } & Skor & Rata-rata & Ket \\
\hline 1 & Menyediakan Harga & Tokopedia.com merupakan aplikasi/ & & & Baik \\
& Kompetitif & $\begin{array}{l}\text { merchant untuk berbelanja dengan harga } \\
\text { yang bersaing dengan aplikasi E-Commerce } \\
\end{array}$ & lain seperti Tokopedia, \\
& Lazada, Blibli, Buka Lapak, olx dll & &
\end{tabular}


Aplikasi Tokopedia.com banyak menjual barang dengan harga yang relatif lebih murah dari pada situs ECommerce lain seperti Tokopedia, Lazada, Blibli, Buka Lapak, olx dll.

2 Menyediakan Jasa Pembelian Yang Tanggap, Cepat, dan Ramah
Penjual yang ada di situs Tokopedia.com merespon pembeli dengan cepat.

Penjual yang ada di situs Tokopedia.com menyediaka informasi produk yang tepat dibandingkan dengan aplikasi lain.

Penjual yang ada di situs Tokopedia.com menyediakan pelayanan yang ramah sehingga konsumen merasa senang belanja di aplikasi ini.

3 Menyediakan

Informasi

Situs Tokopedia.com menyediakan informasi setiap barang yang dijual secara Barang Yang Lengkap lengkap.

Dan Jelas

Situs Tokopedia.com menyediakan fitur pengelolaan stok barang, informasi barang yang jelas dan stok barang otomatis berkurang.

4 Menyediakan Bonus Seperti Kupon, Penawaran Istimewa, Dan Diskon

Aplikasi Tokopedia.com banyak memberikan bonus kepada pembeli diantaranya adalah kupon/voucer belanja, penawaran istimewa dan diskon.

Aplikasi Tokopedia.com sering melakukan penawaran istimewa pada produk fasion, elektronik, pekakas, kesehatan, makanan dan minuman serta produk lainnya.

Tokopedia.com menyediakan fitur diskon dengan berbatas waktu tertentu.

5 Memberikan Perhatian Aplikasi Tokopedia.com menyediakan Khusus Seperti Ulasan ruang untuk mermberikan ulasan setelah Pembelian pembeli melakukan pembelian di aplikasi Tokopedia.com.

Situs Tokopedia.com bisa mengirim foto melalui menu chat bagi pembeli maupun penjual, sehingga memudahkan komunikasi antara pembeli dan penjual

6 Menyediakan Rasa Komunitas Untuk Berdiskusi, Masukan
Situs Tokopedia.com tidak pernah terjadi eror website sehingga pembeli merasa nyaman untuk berdiskusi saat membeli produk di Tokopedia.com.

Penjual yang ada di situs Tokopedia.com menerima masukan dari para pembeli untuk kemajuan toko online yang lebih baik.
402

402

Baik

404

413,5 Baik

405

Baik 409

Baik

408

Baik
403,5

\section{Jumlah}

Rata-rata

408


Berdasarkan tabel diatas diketahui skor rata-rata jawaban sebesar 408 artinya ECommerce dinilai baik oleh konsumen. Dari tabel diatas diketahui bahwa konsumen menempatkan indikator Menyediakan Harga Kompetitif dengan rata-rata skor sebesar 419,5. Sedangkan indikator Menyediakan Jasa Pembelian Yang Tanggap, Cepat, dan Ramah dinilai sebagai yang terendah dengan skor sebesar 402 .

\section{Perilaku Konsumen}

Hasil rekap jawaban responden secara keseluruhan berdasarkan urutan prioritas penilaian perilaku konsumen sebagai berikut:

Tabel 4 Rekapitulasi Jawaban Perilaku Konsumen

\begin{tabular}{|c|c|c|c|c|c|}
\hline No & Indikator & Pernyataan & Skor & $\begin{array}{l}\text { Rata- } \\
\text { rata }\end{array}$ & Ket \\
\hline 1 & Faktor Budaya & $\begin{array}{l}\text { Pelanggan melakukan pembelian di } \\
\text { Tokopedia.com karena dianggap kualitas } \\
\text { produk yang baik dan pengiriman yang } \\
\text { cepat. } \\
\text { Pelanggan membeli produk di situs } \\
\text { Tokopedia.com karena banyak } \\
\text { penawaran yang menarik. }\end{array}$ & 418 & 418 & Tinggi \\
\hline 2 & Faktor Sosial & $\begin{array}{l}\text { Pelanggan melakukan pembelian di situs } \\
\text { Tokopedia.com karena dipengaruhi oleh } \\
\text { teman, tetangga, dan rekan kerja. } \\
\text { Anggota keluarga menjadi acuan untuk } \\
\text { membeli produk di situs Tokopedia.com. }\end{array}$ & 418 & 408 & Tinggi \\
\hline 3 & Faktor Pribadi & $\begin{array}{l}\text { Usia saat ini mempengaruhi pola pikir } \\
\text { pelanggan untuk membeli segala } \\
\text { produk/jasa di situs e commerce } \\
\text { termasuk Tokopedia.com } \\
\text { Pelanggan sering melakukan pembelian } \\
\text { di situs Tokopedia.com karena harga } \\
\text { produk yang dijual sesuai dengan } \\
\text { keadaan ekonomi. }\end{array}$ & 408 & 407 & Tinggi \\
\hline \multirow[t]{3}{*}{4} & Faktor Psikologi & $\begin{array}{l}\text { Pelanggan melakukan pembelian di situs } \\
\text { Tokopedia.com karena pengaruh } \\
\text { lingkungan yang sering menggunakan } \\
\text { ECommerce. }\end{array}$ & 415 & \multirow[b]{2}{*}{405,5} & \multirow[b]{2}{*}{ Tinggi } \\
\hline & & $\begin{array}{l}\text { Setelah mengetahui kualitas produk di } \\
\text { Tokopedia.com, Pelanggan } \\
\quad \text { akan merekomendasikan situs } \\
\text { Tokopedia.com kepada temannya. } \\
\text { Total }\end{array}$ & 3.277 & & \\
\hline & & Rata-rata & 409,6 & Tinggi & \\
\hline
\end{tabular}

Sumber: Data (diolah)

Berdasarkan tabel diatas diketahu rata-rata jawaban sebesar 409,6 artinya perilaku konsumen dinilai tinggi oleh konsumen. Dari tabel diatas diketahui bahwa konsumen menempatkan indikator budaya yang tertinggi dengan rata-rata skor sebesar 418. Sedangkan indikator faktor psikologi dinilai sebagai yang terendah dengan skor sebesar 405,5. 


\section{Analisis Persamaan Regresi Sederhana}

Pengaruh E-Commerce terhadap perilaku konsumen di Kota Jambi dilakukan dengan menggunakan program SPSS versi 21. Berdasarkan hasil yang telah diolah terdapat pada tabel berikut:

Tabel 5 Hasil Regresi Linier Sederhana

Coefficients $^{\mathrm{a}}$



a. Dependent Variable: Perilaku Konsumen

Berdasarkan Tabel 5 hasil iji regresi linier sederhana dapat diperoleh koefisien untuk variable bebas $X=0,843$ dan konstanta sebesar 0,423 sehingga model persamaan regresi yang diperoleh:

$$
\begin{gathered}
Y=a+b X \\
Y=0,423+\mathbf{0 , 8 4 3 . X}
\end{gathered}
$$

Dari persamaan regresi linier sederhana tersebut dapat diinterprestasikan sebagai berikut:

a. Nilai konstanta sebesar 0,423 artinya apabila variabel independent yaitu E-Commerce bernilai nol (0), maka variabel dependen (Y) yaitu Perilaku Konsumen akan bernilai tetap 0,423 .

b. Koefisien regresi variabel E-Commerce bernilai positif sebesar 0,843 artinya apabila variabel E-Commerce mengalami peningkatan sebesar 1 (satu) satuan sedangkan variabel lainnya dianggap konstan, maka variabel $\mathrm{Y}$ yaitu perilaku konsumen akan mengalami peningkatan sebesar 0,843 (jika bernilai positif, variabel $\mathrm{X}$ meningkat dan variabel $\mathrm{Y}$ meningkat).

\section{Uji t (Parsial)}

Hasil analisis regresi output coefficient dapat diketahui thitung sebagai berikut:

Tabel 6 Analisis Uji Parsial (Uji t)

Coefficients $^{\mathrm{a}}$

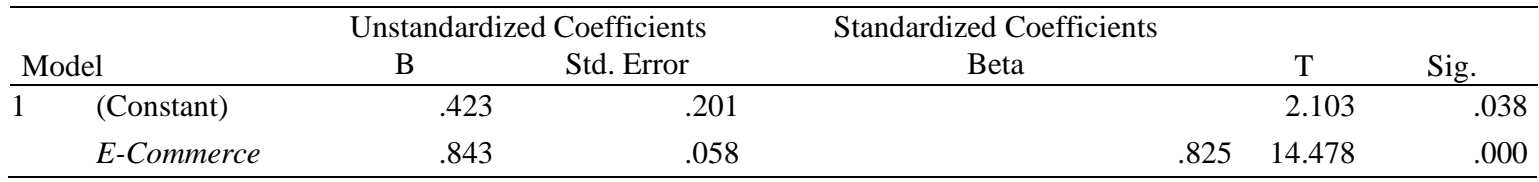

a. Dependent Variable: Perilaku Konsumen

Berdasarkan tabel diatas, dapat diperoleh dengan nilai $t_{\text {hitung }}>t_{\text {tabel }}$ yaitu 14,478>1,984 dan signifikan sebesar $0,000<0,05$. Maka hal ini berarti Ha diterima dengan kata lain bahwa variabel E-Commerce mempunyai pengaruh yang signifikan terhadap perilaku konsumen di Kota Jambi.

\section{Koefisien Determinasi}

Koefisien determinasi digunakan untuk menghitung besarnya variabel independen (ECommerce) terhadap variabel dependen (perilaku konsumen). 
Tabel 7 Koefisien Determinasi

Model Summary ${ }^{b}$

\begin{tabular}{llllrr}
\hline Model & $\mathrm{R}$ & \multicolumn{2}{c}{ R Square } & Adjusted R Square & \multicolumn{2}{c}{ Std. Error of the Estimate } \\
\hline$\underline{1}$ & ${\underline{.825^{\mathrm{a}}}}^{\mathrm{n}}$ & $\underline{.681}$ & .678 & .31773 \\
\cline { 4 - 5 }
\end{tabular}

a. Predictors: (Constant), E-Commerce

b. Dependent Variable: Perilaku Konsumen

Hasil ini menunjukkan bahwa 0,681 jika dipersenkan menjadi 68,1\% menunjukkan nilai E-Commerce mampu menjelaskan variabel perilaku konsumen sebesar 68,1\%, sisanya 31,9\% dijelaskan oleh variabel lain yang tidak diteliti dalam penelitian ini.

\section{Pembahasan Analisis E-Commerce pada Aplikasi Tokopedia di Kota Jambi}

E-Commerce pada Aplikasi Tokopedia di Kota Jambi dinilai baik oleh responden. Hal tersebut dapat dilihat dari rata-rata nilai E-Commerce sebesar 408 jika dilihat pada rentang skala yaitu 340-419 artinya hipotesis mengenai E-Commerce dapat diterima. Dari enam indikator yang digunakan untuk mengukur E-Commerce, responden menempatkan indikator menyediakan harga kompetitif sebagai yang tertinggi dengan skor rata-rata sebesar 419,5 dan indikator menyediakan jasa pembelian yang tanggap cepat, dan ramahyang terendah dengan skor rata-rata sebesar 402 .

\section{Analisis Perilaku Konsumen pada Aplikasi Tokopedia di Kota Jambi}

Perilaku Konsumen pada Aplikasi Tokopedia di Kota Jambi dinilai tinggi oleh responden. Hal tersebut dapat dilihat dari rata-rata nilai perilaku konsumen sebesar 409,6 jika dilihat pada rentang skala yaitu 340-419 artinya hipotesis mengenai perilaku konsumen dapat diterima. Dari empat indikator yang digunakan untuk mengukur perilaku konsumen, responden menempatkan indikator faktor budaya yang tertinggi dengan rata-rata skor sebesar 418 . Sedangkan indikator faktor psikologi dinilai sebagai yang terendah dengan skor sebesar 405,5.

\section{Pengaruh E-Commerce terhadap Perilaku Konsumen pada Aplikasi Tokopedia di Kota Jambi}

Berdasarkan hasil estimasi regresi sederhana, menunjukkan bahwa untuk uji t dari variabel E-Commerce di dapatkan nilai t hitung dengan t tabel sebesar $(14,478>1,984$ dan signifikan sebesar 0,000<0,05), dengan demikian Ho ditolak dan Ha diterima. Oleh karena itu analisis regresi linier sederhana bahwa E-Commerce berpengaruh dan mempunyai hubungan positif terhadap perilaku konsumen pada Aplikasi Shopee di Kota Jambi. Hasil ini di dukung dari teori Anggiani (2016:218) yang mendefinisikan E-Commerce itu sendiri bukan hanya sekedar transaksi keuangan secara elektronik melalui bisnis dan konsumen saja melainkan juga merujuk pada semua mediasi transaksi secara elektronik antara bisnis dan pihak ketiga.

\section{E-Commerce mampu menjelaskan Perilaku Konsumen di Tokopedia Pada Masyarakat Kota Jambi}

Variabel x (E-Commerce) mampu menjelaskan variabel y (Perilaku konsumen) sebesar $68,1 \%$ sedangkan sisanya $31,9 \%$ dijelaskan oleh variabel lain yang tidak disebutkan dalam penelitian ini.

\section{KESIMPULAN}

Berdasarkan pembahasan diatas maka dapat ditarik beberapa kesimpulan sebagai berikut: 
1. E-Commerce di Kota Jambi dinilai sangat baik dengan rata-rata nilai E-Commerce sebesar 408, dan perilaku konsumen dinilai sangat tinggi dengan rata-rata nilai perilaku konsumen sebesar 409,6.

2. Berdasarkan uji hipotesis bahwa E-Commerce berpengaruh secara signifikan terhadap perilaku konsumen di Kota Jambi. Hal ini di buktikan dengan nilai signifikan sebesar $0,000<0,05$. Hasil koefisien determinasi sebesar $68,1 \%$ menunjukkan nilai perilaku konsumen dipengaruhi oleh E-Commerce, sisanya sebesar $31,9 \%$ nilai perilaku konsumen dipengaruhi atau dijelaskan oleh faktor-faktor lain yang tidak diteliti dalam penelitian ini.

\section{Saran}

Berdasarkan hasil penelitian dan pembahasan maka saran yang dapat diajukan adalah sebagai berikut:

1. Hasil penelitian ini diharapkan dapat digunakan oleh masyarakat kota Jambi untuk terus memperhatikan penggunaan media internet.

2. Hendaknya sebagai konsumen untuk terus memperhatikan perilaku yang terkait faktor psikologi untuk membentuk perilaku konsumen yang lebih baik.

\section{DAFTAR PUSTAKA}

Anggiani, Sarfilianty. 2016. Kewirausahaan Pola Pikir Pengetahuan Keterampilan. Jakarta: Prenadamedia Group

Buchari Alma. 2018. Manajemen Pemasaran dan Pemasaran Jasa. Bandung: Alfabeta

Dwi Yulian Saputro. 2018. Analisis Variasi Produk, Harga, E-Commerce Terhadap Perilaku konsumen Pada Toko Komputer Raharja Di Kecamatan Pesantren Kota Kediri. Artikel Skripsi, Universitas Nusantara PGRI Kediri.

Fandi, Tjptono. 2008. Strategi Pemasaran Edisi 3, Yogyakarta: Andi Offset

Ghoribi H.A. dan Djoko, Handoyo. 2018. "Pengaruh E-Commerce, Kualitas Produk dan Promosi Terhadap Perilaku konsumen (Studi pada Batik Mahkota Laweyen, Surakarta)", Jurnal Sosial dan Politik, Universitas Diponegoro.

Hurriyati, Ratih. 2019. Bauran Pemasaran dan Loyalitas Konsumen, Bandung: Alfabeta

I Putu Agus Eka Pratama. 2017. E-Commerce, E-Business dan Mobile Commerce, Bandung: Informatika

Imam Ghozali. 2018. Aplikasi Analisis Multivarite Dengan Program IBM SPSS 25, Semarang: Badan Penerbit Universitas Diponegoro.

Jani Muhammad Ramdhan .2019.. Pengaruh Media Sosial dan E-Commerce Terhadap Perilaku konsumen Distro House Of Smith. Jurnal Manajemen dan Bisnis, Volume 3 Nomor 3

Kotler dan Keller. 2009. Manajemen Pemasaran 